\title{
Male Penile Urethra and Female Urethra Cancer pT1 TNM Finding v8
}

National Cancer Institute

\section{Source}

National Cancer Institute. Male Penile Urethra and Female Urethra Cancer pT1 TNM

Finding v8. NCI Thesaurus. Code C140442.

Urethral cancer with tumor invading subepithelial connective tissue. (from AJCC 8th Ed.) 